\title{
Henry Hopley White (1790-1877) and the early researches on Chalk "Xanthidia" (marine palynomorphs) by Clapham microscopists
}

\author{
WILLIAM A.S. SARJEANT \\ Department of Geological Sciences, University of Saskatchewan, Saskatoon, Canada S7N 0W0
}

\begin{abstract}
In the mid-nineteenth century, a group of microscopists centred in Clapham, London, made significant early contributions to our knowledge of the fossils then known as 'Xanthidia' (and now known to include dinoflagellates, acritarchs and prasinophytes), describing or illustrating many types and formulating far-reaching conclusions concerning their physical character and distribution in sediments. Prominent among them was Henry Hopley White (1790-1877), London barrister and amateur microscopist. An account of White's life is presented and the morphology and present systematic placement of the forms he described are summarized. The new combinations Eatonicysta? vestita (White) and Achomosphaera? malleofera (White), both dinoflageliates: Tasmanites globosus (White), a prasinophycean; and Comasphaeridium fimbriatum (White), an acritarch, are proposed.
\end{abstract}

\section{INTRODUCTION}

In the early part of the nineteenth century, the new world opened to the view of mankind by van Leeuwenhoek's invention of the microscope was proving very intriguing to gentlemen of leisure. Fresh discoveries were being made almost daily and strange structures revealed-the teeming microscopic life in pond water; the strangenesses of the mouth-parts of fleas; and the structure of the stings of bees. Geologists learned to their astonishment, not only that the fossil microscopic remains of animal and plant life were to be found in many ancient sediments. but even composed the great bulk of some strata. Indeed, when that discovery was proclaimed by the German naturalist Christian Gottfried Ehrenberg to the Berlin Academy of Sciences on July 20th, 1837 the whole European scientific community was amazed (see Sarjeant, 1978).

Even before that momentous discovery, the concentrations of microfossils to be found in Recent oceanic sediments had been recognized. Their intricacy and sheer beauty, had intrigued many persons whose scientific concerns were marginal. Soon there was a ready market for prepared slides of foraminifera, diatoms and radiolaria, these being often arranged into elaborate patterns that gave the slides an extra beauty: in England, they were marketed by E. Wheeler of Holloway, C.M. Topping and Edward Suter. Moreover, numerous amateur microscopists were trying their hand at this novel art of mounting and studying such 'animalcules'. Ehrenberg's revelations added a new and exciting dimension to their activities.

In the London suburb of Clapham, a group of these amateur microscopists had formed the Clapham Microscopical Society. Though its records do not survive, this seems likely to have been a group within the Clapham Athenaeum, which is known to have held 'microscopical soirees' (Sarjeant. 1967. p. 241). Among its members were the Rev. J.B. Reade. Henry Deane, H.H. White, who appears to have been its chairman (idem) and probably J.S. Bowerbank and S.J. Wilkinson. the latter being certainly a Clapham resident (Ellison, 1945, p. 145). Most distinguished and percipient of the group, however, was the great surgeon and naturalist Gideon Mantell. All of the above were to publish papers incorporating records and/or illustrations of microfossils observed in thin flakes of Chalk flint.

The Reverend Joseph Bancroft Reade (1801-1870) maty have begun such studies as early as 1836 (Sarjeant, 1982. p. 88). In a letter written to Mantell in December. 1837 and published as an appendix to the latter's Wonders of Geology (1838. p. 684-688. "tabs." 78-80). Reade mentioned and figured what he termed "Infusoria in flint." During Ehrenberg"s visit to England in the summer of 1838 , the German microscopist examined and furnished names for Reade's specimens. When Reade published a more extended account of his work later that year. these were utilized in the captions. All were spiny bodies. considered by Ehrenberg and Reade to be siliceous and attributed to Xanthidium. a genus of freshwater Desmids.

James Scotı Bowerbank (1797-1877) was primarily concerned with sponges. Their remains, he theorized. formed the major part of the flints that were so abundant in Cretaceous strata. His paper "On the Siliceous Bodies of the Chalk, Greensands and Oolite" was read to the Geological Society of London on 11 th March. 1840, and published in three different journals (1841 a-c): but, although he notes that:

Professor Ehrenberg's observations on siliceous bodies 
first induced me, in common with many other persons, to cause thin slices of flint to be made, with the intention of procuring specimens of Xanthidia.... (1841a, p. 181) his mention of the spiny bodies is only incidental and none were illustrated.

Gideon Algernon Mantell (1790-1852) was renowned in his time as a major popularizer of geology, but also he undertook major studies of the stratigraphy and fossils of southeastern England. He is nowadays remembered as the discoverer of Iguanodon and other dinosaurs. In his textbook The Medals of Creation (1844, p. 239-242, text-fig. 53), Mantell recorded and illustrated two species of these micro-organisms, one new and both placed initially into Xanthidium. As it chances, these are the only English 19th-century type and figured specimens of fossil 'Xanthidia' known to survive (Sarjeant, 1967).

However. Mantell was not happy about their systematic assignation, noticing distortions in the shape of processes and walls that indicated flexibility and scarcely accorded with a siliceous constitution. After heating experiments had caused the microfossils to blacken, he concluded that they were organic in composition and could not be Desmids. He suggested instead they they might be 'gemmules of polyparia or the spores of marine plants' (1845).

Mantell proceeded to propose a new generic name, Spiniferites, for them; but unfortunately this was done obscurely, in a footnote in his Pictorial Atlas of Fossil Remains (1850, p. 91). The transfer to this genus of the two forms he had observed in flints was made equally obscurely, in the second edition of The Medals of Creation (1854, p. 91, 239-242, text-figs. 77-79) and the seventh edition of his The Wonders of Geology (1857, p. 311313, text-figs. 58-59). In consequence, with the exception of a single usage by E.W. Wetherell (1892) for microfossils from the Eocene, the name Spiniferites altogether escaped the attention of microscopists until my own rediscovery of it in 1962. The name was readmitted to scientific currency only after spirited controversy (see Sarjeant 1962, 1970).

In the meantime, three other Clapham microscopists had published records of "Xanthidia". Two did so in 1849, in the Transactions of the newly-formed Microscopical Society of London. Henry Deane the elder (1807-1874) - his son and namesake was to be a noted palaeobotanist-was the first to obtain these microfossils from sediments other than flint. $\mathrm{He}$ commented:

...it has been a matter of surprise that the chalk itself surrounding the flints should not have afforded evidence of their existence. So perfectly free from them does it appear, that the prevailing opinion has been, that they had not an independent existence out of the flints themselves, that is to say, floating loosely as independent beings in the seas of the cretaceous period; but that they were immediately connected with the substance, whether animal, vegetable or spongeous, which, in the course of decomposition, has been replaced by the silica, now forming the nodules in which they are found. $(1849$, p. 77)

Distrusting this conclusion, Deane proceeded to make his own investigation:

...I therefore cut out a piece of pyrites of singular form, with the adherent chalk, and afterwards dissolved it out by means of hydrochloric acid. The copious insoluble sediment left after the action of the acid, being examined by the microscope, exposed to view bodies similar to, if not identical with, the Xanthidia in flints.

Though quite evidently unaware of Mantell's work, Deane concurred with his conclusion that these microfossils "certainly appear to have no natural connection with Xanthidia, so called, of our freshwater ponds" (ibid., p. 79).

Among other microfossils remaining after the dissolution were "casts of Polythalamia...the bodies being so perfectly preserved, that in some the lining membranes of the shells are readily distinguished" (ibid., p. 78). This appears to be the earliest recognition of shell linings of foraminifera in a palynological preparation.

Samuel J. Wilkinson (1816-1903) did his most important work in entomology and, in particular, on British butterflies. His only contribution to microscopy was a brief note (1849) in which comparing a living Xanthidium with a hitherto undescribed microfossil from a chalk flint.

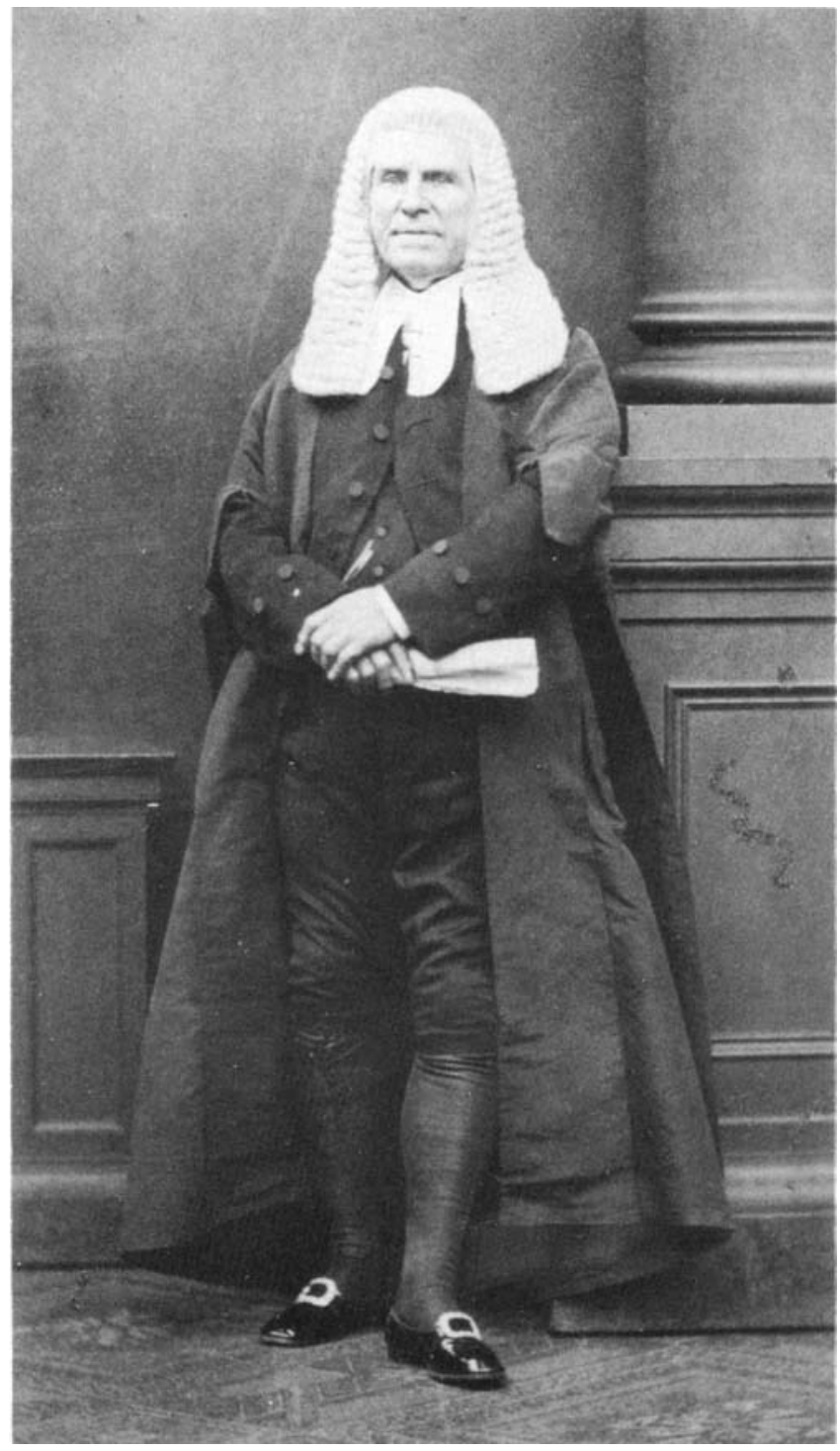

Fig. 1 Henry Hopley White (1790-1877), when elected Bencher of the Middle Temple in 1855. (Photo: Middle Temple, London) 


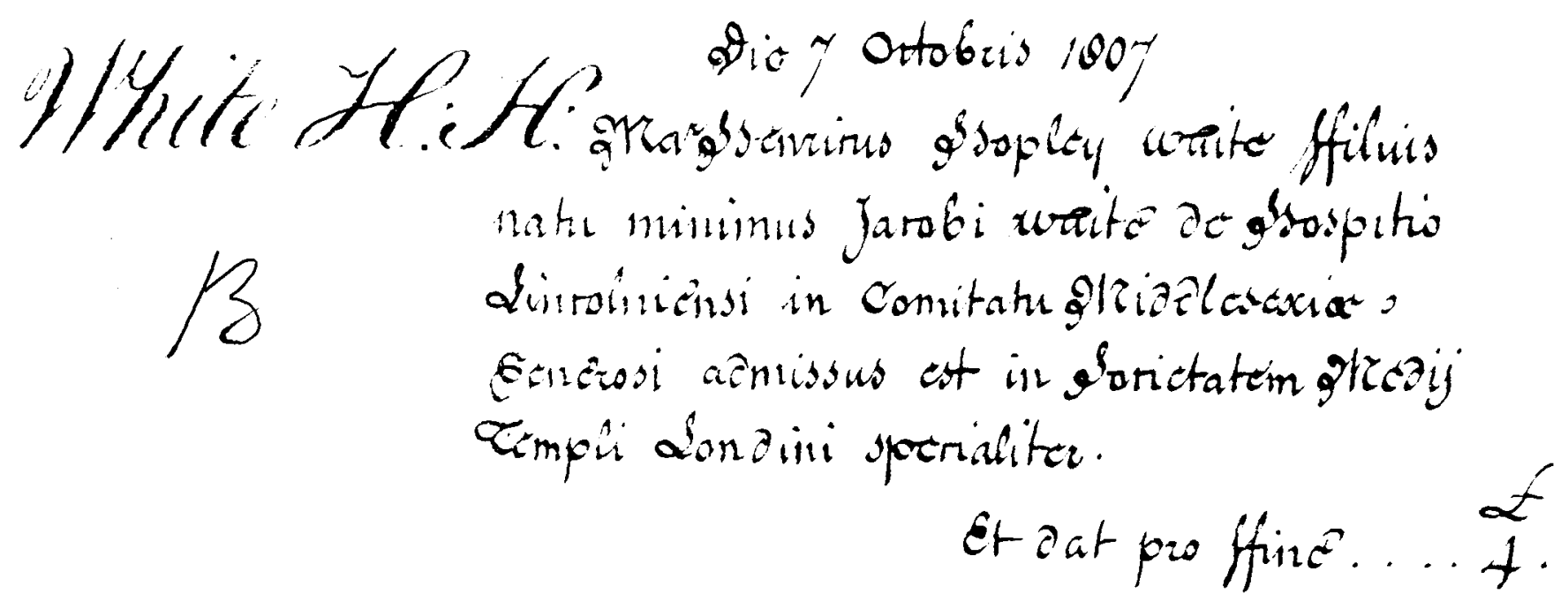

Fig. 2 The manuscript entry recording White's admission to the Middle Temple.

Prior to the publication of the works by Mantell, Deane and Wilkinson, however, there had appeared two papers (one of them published twice, though in slightly different versions) by H.H. White, the central figure of the Clapham Microscopical Society. Neither contributed to knowledge of the composition of the so-called "Xanthidia", nor did they offer any novel palaeoenvironmental information. Nevertheless these papers constitute a landmark in the study of the spiny microfossils, for they contain the fullest descriptions and measurements, and some of the best illustrations, yet published. Indeed, no work of comparable quality was to be done in Britain until the revival of interest in these microfossils more than a century later. Though both the present writer (1967) and H.S. Torrens (1982) have published brief notes on White, no extensive treatment of his life and researches has appeared hitherto. This paper endeavours to redress this deficiency.

Accounts of subsequent researches, by which the "Xanthidia" were determined to be chorate dinoflagellate cysts, have been given elsewhere (Sarjeant, 1967, 1970, 1975) and do not need to be repeated here. However, it should be stressed that the eighteen years of publications by the Clapham microscopists were to be followed by almost a century during which, save for Wetherell's single brief paper (1892), no further original work whatsoever was done in Britain on fossil dinoflagellate cysts.

\section{H.H. WHITE: HIS LIFE AND PROFESSIONAL WORK}

Henry Hopley White was born in London, England in 1790. He was the youngest son of James White, gentleman and armiger, of Chancery Lane. Henry's father was prominent in the legal profession, having been called to the Bar at Lincoln's Inn, one of London's five Inns of Court, on 5th May 1768 and elected a Bencher, i.e. a member of the Inn's governing body, on 9th July 1817.

In a time when family traditions had much more strength than nowadays, it is unsurprising that young Henry should have followed in his father's legal footsteps. He was "admitted to the House", i.e. accepted as a student member, at the
Middle Temple, another of the Inns of Court, on 7th October 1807 upon payment of the customary $£ 4$ entry fee (see Fig. 2 ). Twelve days later, he matriculated to Oriel College, Oxford.

Upon completing his education, Henry White worked from 1814 to 1818 as a conveyancer, engrossing legal documents, he was called to the Bar of the Middle Temple on 27th November 1818. Thereafter he practised as a barrister-at-law, conducting cases in court. His ability in his profession is demonstrated by the tasks to which he was appointed and the honours which he gained. Not only did he edit both the third, two-volume edition (1828) and the fourth edition (1847) of Roper's classic Law of Legacies, but also the fourth English and first American editions of Cruise's Digest of the Law of England respecting Real Property, a formidable seven-volume work to which White contributed a new chapter on "Merger". In 1866 he was honoured by being appointed a Queen's Counsel.

Either because of filial sentiment or paternal influence-the latter seems likelier!-Henry White occupied chambers at 13 Old Square (and briefly, in 1819, at 7 Old Square), Lincoln's Inn from 1814 until retirement in 1876; it is, in fact, by no means uncommon for a barrister of one Inn to have chambers in another. Certainly Henry's association with the Middle Temple was strong. He was elected a Bencher on 31st January 1855. remaining so to the end of his career. In addition he served as Reader, giving the Autumn reading in 1858, and as Treasurer, the Temple's most senior office, in 1865. This caused his arms to be depicted on a panel in the Middle Temple Hall; they are here illustrated (Fig. 3) and may be blazoned as:

Gules, a bordure sable charged with fourteen estoiles or, on a canton argent a lion rampant of the second.

A photograph of White in his robes is preserved in the Temple's archives and is here reproduced (Fig. 1). It is the only portrait of White that is known to survive.

White resided at The Firs. Rectory Grove, Clapham--a most respectable London suburb, which a professional man might very properly inhabit. Concerning his personal life, no information has been forthcoming. even on such major questions 


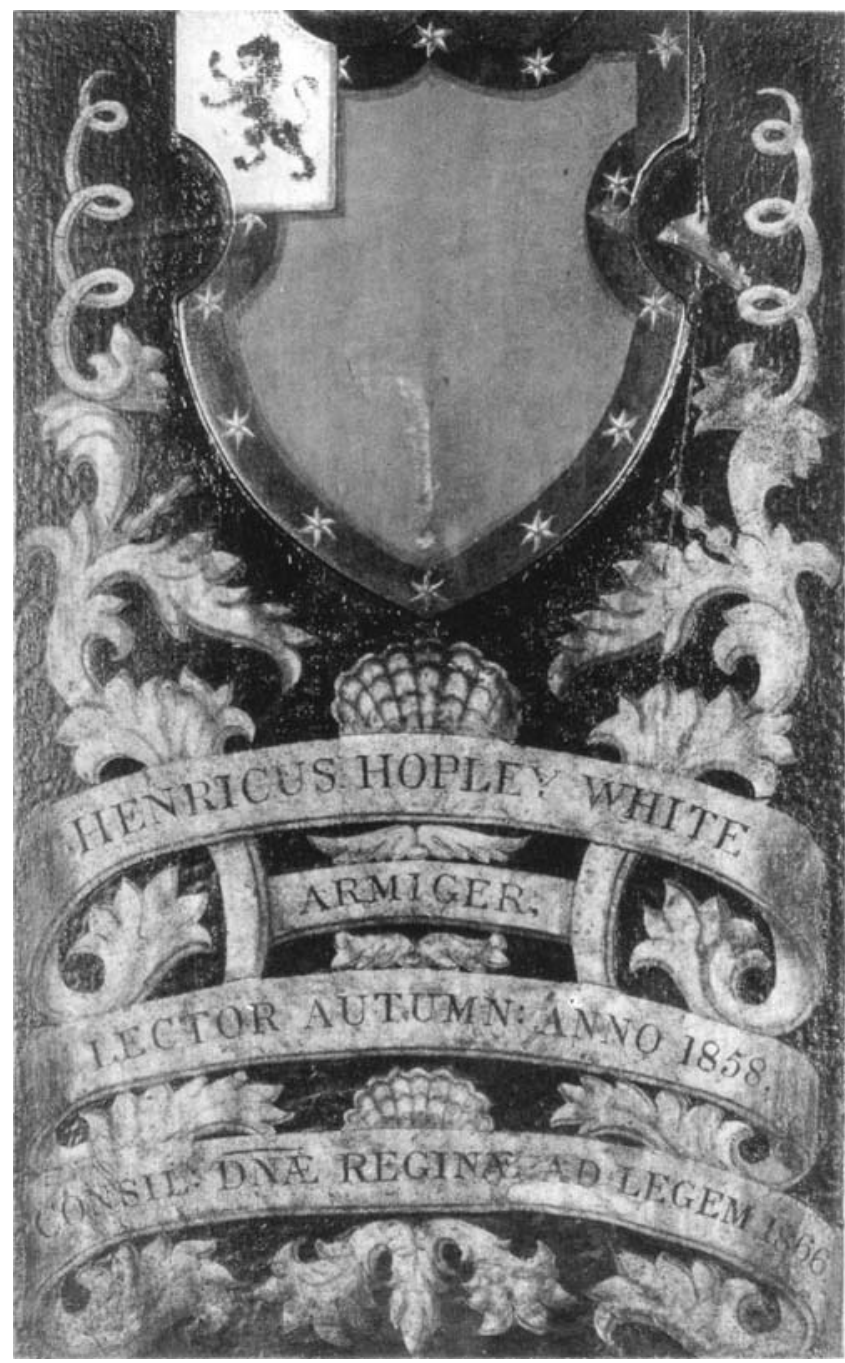

Fig. 3 Armorial bearings and honours of Henry Hopley White; from a panel in the Middle Temple Hall, dating from his year as Reader.

as whether he had a wife and children. He was a member of the Clapham Athenaeum and a pivotal member of the Clapham Microscopical Society, sufficiently so that, when a microscope was bought by subscription for presentation to Gideon Mantell, it was considered fitting that White should make that presentation. Mantell's journal for the year 1842 reports the occasion thus:--

MARCH 29.--Mr. Henry Hopley White presented me with a Microscope and apparatus, of the very first description by Ross, of the value of 90 guineas, in the names of my friends in Clapham, with the following inscription--'Presented to Gideon Algernon Mantell Esq., LL.D., F.R.S. etc. by his friends in Clapham and its vicinity in testimony of their grateful sense of his kind and effective exertions among them for the advancement of scientific knowledge. February 3rd, 1842' - The proposal to present me with this testimonial originated with Miss Zornlin of Clapham, a very superior woman, authoress of Recreations in Geology, etc.Miss Z. and her sister, Mr. and Mrs. and Misses Allnutt, Miss Foster and a few other friends spent the evening with me, and Mr.
White displayed the splendid instrument which is of the highest excellence.

MARCH 30.- Mr. White spent this evening with me in examining the powers of the Microscope. My dear boy Reginald who is at home for the Easter holidays, is very busy with his microscopical investigations. (Curwen, ed., 1940, pp. 152-153)

It is likely enough that White's interest in flint microfossils was stimulated by his friend Rev. Joseph Reade, but confirmation is lacking. White was an early member of the Microscopical Society of London (now the Royal Microscopical Society), being elected in 1841. It is likely that the formation of that larger Society spelled the demise of the Clapham group of microscopists. The Clapham Athenaeum, probably its parent body, was to survive much longer but appears thereafter to have progressively lost interest in microscopy.

The paper read by White to the Microscopical Society on February $16 \mathrm{th}, 1842$, was his major contribution to micropalaeontology. It was reported immediately in the Microscopical Journal (1842), his second name being misspelled, and then published in full in the Society's Transactions two years later (1844a). There were a few modifications; in particular, a lengthy footnote on the first page contained fresh taxonomic proposals were made concerning one of the forms described. Later in the same year a short note by White, describing a further type of "Xanthidium", likewise appeared in the Transactions (1844b).

Though White lived for over thirty years longer, he did not write again upon microfossils. He died at his Clapham home on 13th January 1877, having almost attained the venerable age of 87 years.

\section{H.H. WHITE: HIS STUDIES OF FOSSIL DINOFLAGELLATES - PREAMBE}

White's introduction to his address merits quotation in full, since it specifies his concerns and sets the microfossils into their contemporary systematic context:

I have, for some time past, directed my observations to that interesting portion of fossil Infusoria called Xanthidia, and which, in the recent state, forms a genus of the tenth family of the class of Polygastrica, called Bacillaria. In this genus the animalcule is unattached, and free from any pedicle or stalk: having a globular form, generally spherical, but in some of the species occasionally of an irregular oval. All the species of this genus have the lorica or external covering semi-transparent, and invested with tentacula, varying in form, number and dimensions: from these tentacula, each of the different species may, with little difficulty, be discovered. The arrangement which I am about to submit to the Society, of the different species of this interesting group of fossil Infusoria, is the result of much careful examination of some thousands of specimens, in flint collected from various chalk districts of England, and in some gravel flints.

The name Xanthidium is derived from the Greek word, yellow, the prevailing hue of these minutissimal forms of animal existence. (1844a, p. 77)

In the ensuing discussion, White comments

The classification hitherto recorded I consider very imperfect-Professor Ehrenberg does not, I believe, include more than five or six species, and assigns to a distinct species some which I deem distorted varieties. The want of a nomenclature to characterize those which in my continued observations were so 
constantly recurring, induced me, for my own convenience (and without the most remote intention of offering the result to this Society) to adopt the arrangement of the species under the number and nomenclature I now proceed to suggest. (1844a, p. 78)

Twelve species were thereafter distinguished. The order of their treatment differs in the two papers $(1842,1844 \mathrm{a})$, the arrangement of the plates being correspondingly modified. Their character and present systematic assignation are discussed below, revised diagnoses being furnished wherever necessary. However, it should be stressed that White's types are lost, prolonged enquiries by the present author having proved unsuccessful in locating them in any British museum collection. All past reassignations have thus been made entirely on the basis of White's drawings and descriptions, as indeed are the discussions and revisions here presented.

White's measurements were originally expressed awkwardly as fractions of an inch. Their metric equivalents are here given; but it should be recognized that these must necessarily be imprecise, since the limitations of White's microscope made it impossible for him to attain a precision comparable to that attainable today.

White believed his "Xanthidia" to be, "beyond all doubt...animal and not vegetable substances" (1844a, p. 84), a conclusion based upon the mobility of the processes of living forms. Evidently he assumed that all plants, even when of microscopic dimensions, must be incapable of independently moving their spines or other processes-an assumption demonstrated subsequently to be false. Moreover, White accepted the current opinion that the fossils had been, like the enclosing flint masses, silicified:

Whether, by a sudden transformation, the surrounding fluid which contained these minute and delicately organized modifications of animal existence we have been describing, was, with its numerous inhabitants, converted into its present condition of flint; or whether, by the gradual deposit of minute particles of silex, held in solution by the fluid which contained these minute animalcules, the continuous aggregation became nodules of flint, as we now find them, in various chalk districts in England; or whether, by some other wondrous and inscrutable agency, a process altogether different from either of those supposed, these mausoleums of countless myriads of once living beings (now fossil Infusoria) were produced;--I feel myself incompetent to surmise, having but little acquaintance with those sciences which bear upon this subject of acknowledged difficulty. But certain it is that mere appearances would seem to justify the first hypothesis of sudden transformation, however it may militate against the more favoured opinions of geologists, versed also in the science of chemical agency. It cannot fail to arrest attention, that delicate as is the structure of these minutissimal creatures, there is not, in by far the greatest proportion of them, any appearance of distortion, pressure, or injury of any kind; they seem to have been suddenly arrested in the full enjoyment of life, developing (so far as form and perfect structure can evidence the fact) every indication of animation exhibited by the recent species, up to the very moment of their transformation from the living to the fossil animalcule. (1844a, pp. 84-85)

He concluded with a burst of philosophy and even poetry:

...we have, in these flints, records of animal existence, as convincing and irrefragable as in those more gigantic memorials of the earth's inhabitants in former epochs of its dark history, whether in the form of the Ichthyosauri, the Iguanodon, or the fossil remains of beings of still more remote antiquity. We have, in every section of a flint nodule, proofs that in the former periods of the surface of our planet, the lines of the poet were then, in part at least, as applicable as now, when he says--

"See through this air, this ocean and this earth,

All matter quick and bursting into birth."

Neither will the cloud of impenetrable mystery which hangs over the earlier changes of the earth's surface, prevent the accurate observer of the countless reliqui of its former wonders from admiring the same indications of infinite wisdom and power, which still captivate the devout philosopher in his investigation of those teeming myriads of living animalcules, now existing in almost every modification of matter, which clothes its present surface with beauty, fertility and abundance. (ibid., pp. 85-86)

To the twelve fossil forms distinguished in the two versions of this paper, there was added a description and illustration of a thirteenth, in a short paper published by White later in 1844. The present systematic attribution of these thirteen types of microfossils is considered in the section that follows. Brief quotations are given from White's descriptions, to demonstrate the quality and care with which he worked on his microfossils.

\section{THE PRESENT SYSTEMATIC ATTRIBUTION OF WHITE'S "XANTHIDIA"}

White's illustrations were remarkably good, considering the quality of microscope available to him, and his descriptions were, at that date, perfectly adequate. However, in recent years a number of features, which would not have seemed important to him, have proved to be of crucial significance; and, since the specimens he figured are lost, the reassignments that follow are made with very variable confidence. The figure numbers relate to the later version (1844a, pl. 8) of White's principal paper: the dimensions are recalculated from White's measurements which, made as they were in small fractions of an inch, very definitely illustrate the scientific advantages of metric measurement!

Fig. 1 Xanthidium vestitum White (Diameter overall $63.5 \mu \mathrm{m}-9$ l $\mu \mathrm{m})$ "...which I so name from the thin transparent membrane which extends beyond the body to the extremity of the tentacula, and by which the animalcule appears to be surrounded" (White, $1844 a$, p. 78 ). He noted also that the membrane "is rarely seen to encompass the animalcule as perfectly as...delineated" since it is "more or less broken around the outer circumference". He speculated that this appearance resulted "from a gelatinous substance in which the animalcule was enveloped" (ibid., pp. 7879).

This specimen is, of all those illustrated by White, the most difficult to assign. The description suggests a dinoflagellate cyst such as Membranilarnacia, Eatonicysta or Nematosphaeropsis, especially since White noted (p. 79) that "sometimes the membrane seems to adhere to two or three tentacula, at other times to one only." The illustration, however, occasions doubt. On the one hand, this might be a cyst such as Silicisphaera torulosa Davey and Verdier 1976. [Note: Duxbury's (1980, p. 119) treatment of the genus Silicisphaera Davey and Verdier, 1976, as a junior subjective synonym of Florentinia 
Davey and Verdier, 1973 is not accepted by the writer]. On the other hand, it might be a spore, a possible comparison being found in Retitriletes austroclavatidites (Cookson, 1953) Doring et al. in Krutzsch, 1963. However, White's species is certainly not a Xanthidium and should not be allowed to remain in that genus. In consequence, the following new combination is very tentatively proposed, more on the basis of the textual description than of the illustration:-

Eatonicysta? vestita (White, 1842, p. 36, pl. 4 div. 3 fig. 2) Sarjeant, comb. nov. Late Cretaceous, southeastern England. (Formerly Xanthidium vestitum).

Fig. 2 Xanthidium fimbriatum White (Diameter overall $50.8 \mu \mathrm{m}$ $84.6 \mu \mathrm{m})$. Named "from the short processes or stunted tentacula which densely surround the body" (1844a, p. 79). White did not attempt to count the processes, considering it to be "indeed...scarcely practicable" (idem). This species was transferred to the genus Hystrichosphaeridium by Deflandre, in his Fichier micropaleontologique card-file series (1946, card 1499). (Since at that time the "hystrichospheres" were of unascertained affinity, this did not imply a dinoflagellate affinity). Later the species was transferred to the genus Baltisphaeridium, invalidly by Sarjeant, 1959, p. 339 and validly by Downie and Sarjeant, 1964, p. 91. However, that acritarch genus, as revised, no longer embraces forms with such a high process density. Instead, it is here considered to have been almost certainly a dinoflagellate cyst and the following new combination is proposed:

Comasphaeridium fimbriatum (White, 1842, p. 36, pl. 4 div. 3 fig. 3) Sarjeant, comb. nov. Late Cretaceous, southeastern England. (Formerly Xanthidium fimbriatum: later Hystrichosphaeridium and Baltisphaeridium).

Fig. 3 Xanthidium hirsutum Ehrenberg (Diameter overall $50.8 \mu \mathrm{m}$ - $89.1 \mu \mathrm{m})$ "...so called from the hairy or furred appearance which the numerous thin tentacula assume, being in tufts" that are not markedly "uniform and regular in their arrangement" (White, $1844 a$, p. 79). White notes this as being a "name...given to it by its former observers and, among them, by that accurate observer, the Rev. J.B. Reade" (idem.). In fact, the name was first applied to a living desmid, now Staurastrum hirsutum (Ehrenberg) Ralfs; it application to the Chalk microfossils was from the outset incorrect (see discussion in Sarjeant, 1984, p. 131-132).

All the fossil forms are certainly dinoflagellate cysts. Ehrenberg's forms are now placed into Coronifera striolata (Defandre. 1937) Stover and Evitt, 1978. However, the forms illustrated by Reade and White are markedly different, having a much higher number of processes. They are now assigned to a species named after White, Cometodinium? w'hitei (Defandre and Courteville, 1939) Stover and Evitt, 1978.

Fig. 4 Xanthidium furcatum Ehrenberg (Diameter overall $50.8 \mu \mathrm{m}$ - $84.6 \mu \mathrm{m}$ ). A form having "tentacula...far less numerous, more separated, more regularly arranged. and divergent from the common centre of the animalcule." being "slender, and gradually tapering to an extremity" (White, 1844a, p. 80). X. furcatum is one of two species distinguished by White that were originally described by C.G. Ehrenberg from German flints, the other being $X$. ramosum. Subsequently Maria Lejeune (1937a, b; Lejeune-
Carpentier, 1937) showed these two types to have an overlapping morphological range; and ultimately Davey and Williams (1966a, p. 29-33) proposed that they be treated as synonyms. The name ramosum was preferred by those authors because its holotype survives, whereas that for $X$, furcatum is lost. The correct present name of this dinoflagellate cyst is spiniferites ramosus (Ehrenberg, 1838) Mantell, 1850.

However, White's illustration and description do not agree with Ehrenberg's species. Instead, they are of a form having many more processes, "from thirty to forty...or even more" being "apparent round the circumference" and a rough computation of the total being "perhaps from two to three hundred" (White, 1844a, p. 80). An attribution to Cometodinium obscurum Deflandre and Courteville, 1939 seems much more appropriate.

Fig. 5 Xanthidium spinosum White (Diameter overall $50.8 \mu \mathrm{m}$ $101.6 \mu \mathrm{m})$, "which I so name from the singularly long tapering tentacula which characterize this species" (1844a, p. 80). This form was treated as a hystrichosphere by Lejeune-Carpentier (1941, p. B76) and placed into the genus Hystrichosphaeridium, now known to embrace chorate dinoflagellate cysts. Subsequently it was again transferred by Davey (1969, p. 166), becoming Exochosphaeridium spinosum (White) Davey. No redescription has yet been attempted, nor has the species name been applied to specimens from elsewhere.

Fig. 6 Xanthidium malleoferum White (Diameter overall $63.5 \mu \mathrm{m}$ - $87.6 \mu \mathrm{m}$ ) "...from the Latin words malleus, a hammer, and fero, to bear.... The tentacula of this species are for the most part terminated by a small process or arm, placed nearly at right angles, at the extremity of each tentaculum, which nearly bisects the little arm, and which thus forms the head of a hammer" (1844a, p. 80). The "tentacula" were observed to be of variable length and to range in number from fifteen to fifty. White noted that the central bodies of different individuals were "sometimes...spherical, and at others irregularly elliptical", being "frequently broken on one side" (ibid., p. 81)-the latter constituting an early observation of what must surely be precingular archaeopyles. Deflandre (1937, p. 31) considered this species to be a hystrichosphere, placing it into Hystrichosphaeridium. Downie and Sarjeant (1963, p. 91) echoed Deflandre's uncertainty concerning its affinities, placing the species into Baltisphaeridium only because its processes are closed distally. Upon re-reading White's description-the form of the processes, the variability of shape and the presence of what must surely be a precingular (type P) archaeopyle - I am in no doubt that this must be a dinoflagellate cyst. The distal process terminations described by White are surely those of sutural processes; it is reasonable to suppose that gonal processes would end in three branches. However, since that is conjectural, the generic placement here suggested must be tentative:

Achomosphaera? malleofera (White, 1842, p. 37 , pl. 4 div. 3 fig. 7) Sarjeant, comb. nov. Late Cretaceous, southeastern England. (Formerly Xanthidium malleoferum White 1842: subsequently Hystrichosphaeridium and Baltisphaeridium).

Fig. 7 Xanthidium ramosum Ehrenberg (Diameter overall 63.5 

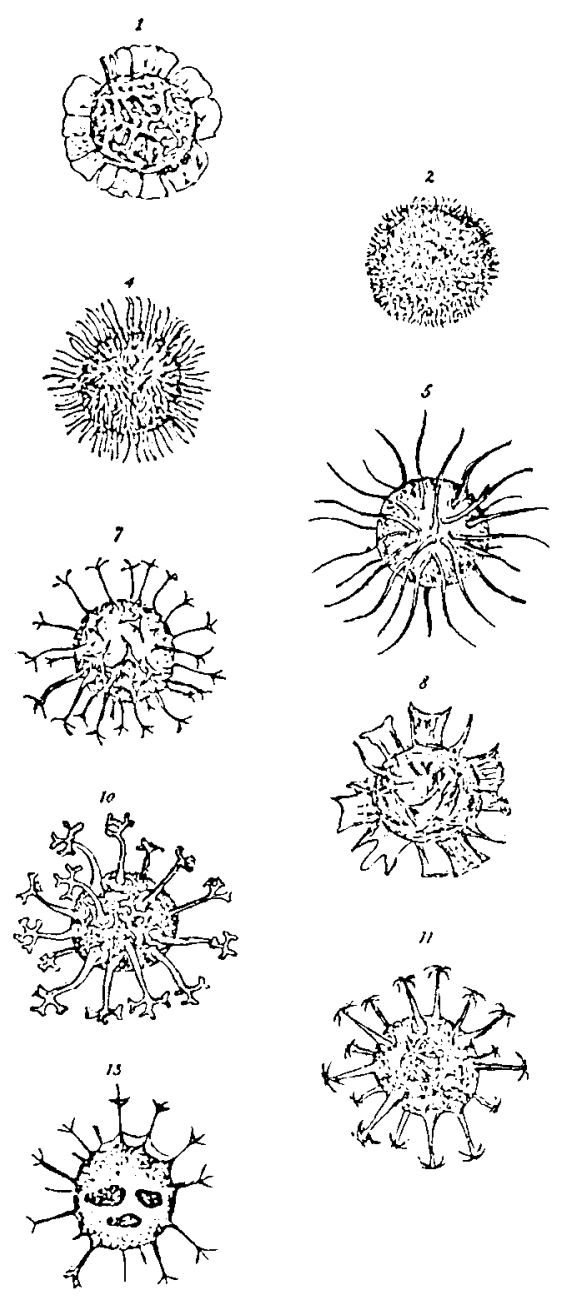

8
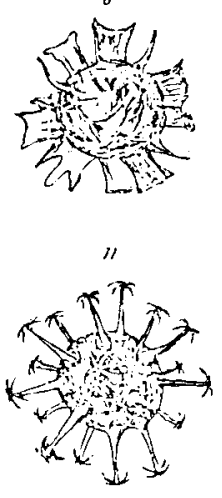

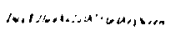
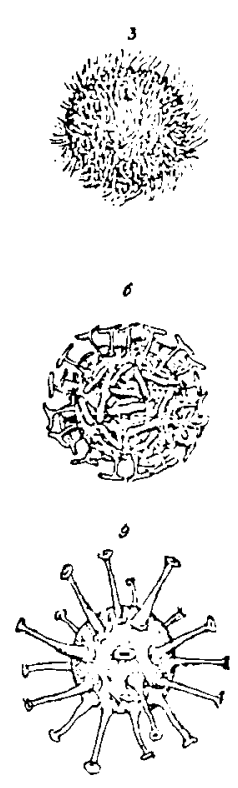

$1 z$

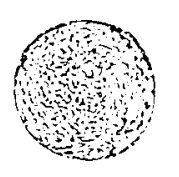

14

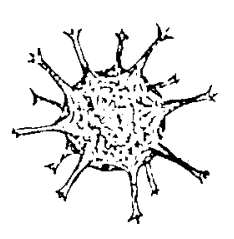

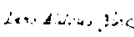

Fig. 4 White's plate of "fossil Xanthidia" (1844a)

1 Xanthidium vestitum, now Eatonicysta? lestita (White) Sarjeant. comb. nov.

2 Xanthidium fimbriatum, now Comasphaeridium fimbriatum (White) Sarjeant. comb. nov.

3 Xanthidium hirsutum, now Cometodinium? whitei (Deflandre and Courteville) Stover and Evitt

4 Xanthidium furcatum, now Cometodinium obscurum Deflandre and Courteville

5 Xanthidium spinosum, now Exochosphaeridium spinosum (White) Davey

Xanthidium malleoferum, now Achomosphaera? malleofera (White) Sarjeant. comb. nov.

Xanthidium ramosum, now Spiniferites ramosus var. gracilis Davey and Williams

Xanthidium crassipes, now Hystrichokolpoma? 'rassipes (Reade) Lejeune-Carpentier and Sarjeant

Xanthidium (Tubiferum) simplex, now Dapsilidinium simplex (White) Bujak. Downie. Eaton and Williams

Xanthidium (Tubiferum) complex, now Oligosphaeridium complex (White) Davey and Williams 
$\mu \mathrm{m}-84.7 \mu \mathrm{m})$ "...the most common of all the eleven species. There are several varieties: the tentacula round the apparent circumference varying in number from fifteen to thirty: the average number is about twenty.... [The] terminations of the tentacula are generally three in number, diverging from the end...not unlike a bird's foot, only longer in proportion and more tapering: but sometimes they are of a more complex structure, each of the three arms or terminations branching out again at their extremities into further processes..." (White, 1844a, p. 81).

White's observations anticipate the recognition by Lejeune (discussed above) of the high variability of this species; a number of varieties were to be nomenclatorially distinguished by Davey and Williams (1966a). The specimen illustrated in White's plate (1844a, pl. 1 fig. 7) appears to be of Spiniferites ramosus var. gracilis Davey and Williams, 1966a, seen in apical view. In contrast, his second text-figure (ibid., p. 81) shows terminations according with those of the typical variety, S. ramosus var. ramosus.

Fig. 8 Xanthidium crassipes Reade (Diameter overall $90.7 \mu \mathrm{m}$ $101.6 \mu \mathrm{m}$ ) "The outer margins of the thick tentacula are very irregular in form, generally indented or waved; and this thickness would seem to be formed by a membrane connecting two or three of the smaller tentacula", the latter being simple (White, 1844a, p. 82). This species, originally illustrated by Reade (1839, pl. 9 fig. 2 ), is unquestionably a dinoflagellate cyst. After being subsequently placed into Hystrichosphaeridium (LejeuneCarpentier, 1941, p. B79-80) and questionably into Litosphaeridium (Davey and Williams in Davey et al., 1969, p. 5), it is now attributed doubtfully to Hystrichokolpoma, as H.? crassipes (Reade) Lejeune-Carpentier and Sarjeant, 1981, p. 1012. A specimen from the Craie de Spiennes (Late Cretaceous) of Cuesmes, Belgium, originally illustrated and described by Lejeune-Carpentier (1941, fig. 9) and redescribed and reillustrated by Lejeune-Carpentier and Sarjeant (op.cit., p. 10-11, pl. 3, fig. 3, text-fig. 6) was selected as neotype.

Fig. 9 Xanthidium tubiferum simplex White (Diameter overall $101.6 \mu \mathrm{m}$ ) "or, leaving out the generic name, Tubiferum simplex: because the tubiform tentacula have a simple termination, that being of a plain circular orifice, slightly curving outwards, like the end of a trumpet or hautboy, perhaps not unlike the mouth of a leech when fixed, and in the act of drawing blood" (White, 1844a, p. 82). This first of "three Tubifera or tube-bearing Xanthidia" described and figured by White is again a dinoflagellate cyst. It was assigned to Hystrichosphaeridium in the Fichier micropaleontologique card catalogue (Deflandre, 1946, card 934) and later questionably to Polysphaeridium (Davey and Williams in Davey et al., 1969, p. 6). It is presently placed into Dapsilidinium, as D. simplex (White) Bujak et al. (1980, p. 28). Though Lejeune-Carpentier (1940) was to style 'hystrichospheres' of this general type as 'Tubiferes', the name Tubiferum, presumably intended 10 characterize a subgenus, has never come into use.

Fig. 10 Xanthidium complex White (Diameter overall $84.6 \mu \mathrm{m}$ $254 \mu \mathrm{m}$ : the latter figure appears remarkably high). "[The] tubiform tentacula have branching terminations or processes, but which are not uniform in their structure. Sometimes the orifice is separated into unequal divisions of four, five or six parts" whereas in other instances "the branching terminations [are] of a more complex structure...each branching having at its extremes a further ramification" (White, 1844a, p. 83). White's careful drawings (ibid., p. 83) illustrate the variation in process terminations, with a care not to be equalled until Lejeune's studies of the 1930's.

The nomenclatural history of this species, again certainly a dinoflagellate cyst, was summarized by Davey and Williams (1966b, pp. 71-74). They transferred it to the genus Oligosphaeridium, as $O$. complex (White) Davey and Williams, and proposed a neotype from the English Chalk. This species has been very widely encountered in Late Cretaceous sediments; a comprehensive synonymy and review is given by Harker, Sarjeant and Caldwell (1990, p. 59-62).

Fig. 11 Xanthidium tubiferum recurvatum, palmaforme or palmatum White (Diameter overall $76.9 \mu \mathrm{m}-90.7 \mu \mathrm{m}$ ) “...differs from the two preceding in having the tentacula decorated at their terminations with a cluster of smaller curved processes, diverging from the orifice of each tentaculum, and inclining back in the form of a cluster of palm-leaves, from four to six in number."

The confusion caused by White's presentation of three alternative names for this taxon has been considerable. Bronn (1848, p. 1375) selected the epithet palmatum; and this was the name used when Mantell (1851, p. 251, text-fig. 79) transferred the species to Spiniferites. Unfortunately, these early works remained long unnoticed. When Lejeune-Carpentier (1940, p. 221) transferred the species to Hystrichosphaeridium, she selected the name recurvatum instead; and even though Davey and Williams (1966b, pp. 67-68) considered the problem in full awareness of the earlier names, they preferred the latter name.

Further to complicate the situation, Deflandre and Courteville (1939, p. 101, pl. 3 fig. 1) had in the meantime utilized the name Hystrichosphaeridium palmatum for forms of quite dissimilar morphology from French Late Cretaceous flints. Their species was treated as an acritarch, and transferred to Baltisphaeridium, by Downie and Sarjeant (1963, p. 91): but Davey, Downie, Sarjeant and Williams (1969, p. 16) considered it to be a dinoflagellate cyst and reattributed it questionably to the genus Exochosphaeridium. Yun (1981, p. 29) believed the species to be a junior synonym of Pervosphaeridium pseudhystrichodinium (Deflandre) Yun. However, since Deflandre himself found good grounds for distinguishing the two species, Yun's judgement appears questionable.

Before the work of Davey and Williams (1966b), Sarjeant (1964, pp. 174-175) had considered the nomenclatural problem and had concluded that the name palmatum should properly supersede recurvatum. This opinion was endorsed by Stover and Evitt (1978, p. 57). In contrast, Lentin and Williams $(1989$, p. 185) considered that the brief sojourn in the genus Hystrichosphaeridium of Deflandre and Courteville's species palmatum pre-empted the combination Hystrichosphaeridium palmatum. Consequently, presumably evoking (but not citing) Art. 54 of the International Code of Botanical Nomenclature (Voss et al., 1983), they rejected White's species name and proposed in substitution the new name Hystrichosphaeridium duplum. Their decision, though historically unfortunate, appears legalistically correct. The name they chose was not explained, but seems to be a 


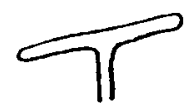

1

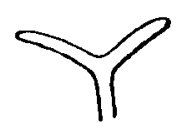

2

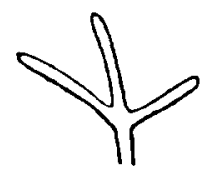

3

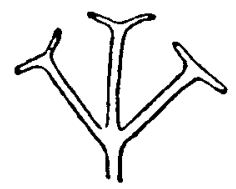

4

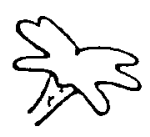

5

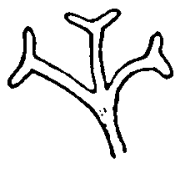

6

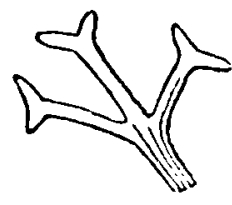

7

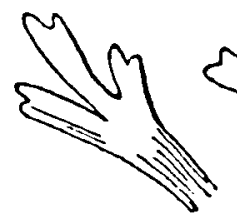

8

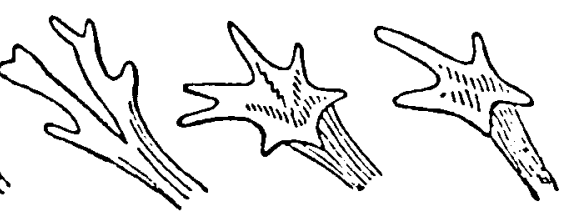

10

Fig. 5 White's detailed drawings of the processes on his "fossil Xanthidia".

1-2 Xanthidium malleoferum, now Achomosphaera? malleofera (White) Sarjeant, comb. nov.

3-4 Xanthidium ramosum, now Spiniferites ramosus var. gracilis Davey and Williams.

5-11 Xanthidium (Tubiferum) complex, now Oligosphaeridium complex (White) Davey and Williams.

Fig. 6 Xanthidium spiculatum White, 1844b, now Baltisphaeridium spiculatum (White) Downie and Sarjeant

humorous reference to the penalties suffered by poor White for taxonomic impropriety! (L. duplum, double; esp. a double penalty).

Fig. 12 Xanthidium globosum (Diameter $50 \mu \mathrm{m}-74 \mu \mathrm{m}$ ), "a globular form, without tentacula, spines, aperture, or other variation of the surface" (White, 1842, p. 36). Later, White raised this to generic status as Globosum (1844a, p. 77, footnote), without furnishing any trivial name for its type (and only) species. Consequently, its publication appears to contravene the requirements for valid publication in the International Code of Botanical Nomenclature, in particular Arts. 10 and 42. Certainly the generic name Globosum White has not been utilized by any subsequent author. Instead, in his "Fichier Micropaleontologique", Deflandre (1946, card 993) transferred White's species tentatively to the genus Leiosphaera. When that genus was demonstrated to be a junior homonym, Downie and Sarjeant (1964, p. 124) placed it into the "successor" genus Leiosphaeridia of sphaeromorph acritarchs.

A restudy of White's careful drawing, however, indicates a surface texture that, while not at all characteristic of leiospheres, is very typical of tasmanitids, the fossil porous-walled zoosporangia of prasinophycean algae akin to the living genera Pachysphaera and Halosphaera. Although the dimensions quoted are small for tasmanitids, they fall within the known range; indeed, Sarjeant (1973, p. 67, pl. 3 fig. 8, pl. 6 fig 5) has reported a Triassic tasmanitid of diameter only $29.5-34 \mu \mathrm{m}$. Moreover White (1844a, p. 77, footnote) remarked that his form lacked an aperture and was nearly opaque, a feature suggestive of an unusually thick wall-both features according well with this concept. In consequence, the following new combination is proposed:-

Tasmanites globosus (White, 1842, p. 36, pl, 4 div. 3 fig.
1) Sarjeant, comb. nov. Late Cretaceous, southeastern England. (Formerly Xanthidium globosum White, 1842: subsequently Globosum, Leiosphaera? and Leiosphaeridia?).

Fig. 13 Xanthidium ramosum Ehrenberg, variety. "I possess one which is very remarkable, and the only one among some hundreds which I have discovered. The body is transparent, and within it are three red globules most clearly apparent, of an irregular oval or oblate form, composed as it would seem of a cluster of minute molecules; whether these are ova or clusters of embryo Xanthidia I cannot determine" (White, 1844a, p. 81).

White's drawing suggests a specimen of Spiniferites ramosus var. gracilis Davey and Williams, 1966a, in dorsal or ventral view; but the nature of the three red globules-certainly not ova, since this is a cyst-remains a matter for speculation. Were they a residue of the cell contents (perhaps the eye-spot pigments) or the remains of bacteria?

[Fig. 14 illustrated a recent Xanthidium-i.e. a veritable Desmidfrom New York, for comparative purposes].

A last species of 'fossil Xanthidium' was described and illustrated in White's final short paper (1844b, p. 87, pl. 20 fig. 4):

Xanthidium spiculatum White (Diameter overall 158.8 um) "...it differs from the three species of Tubifera described in my former paper, in the following particulars:- that the tentacula are longer, and instead of possessing any process at their extremities, they gradually taper to the finest point: the tentacula apparent are from eleven to twelve, quite straight, and free from any appendage whatever" (White. 1844b, p. 87).

This species was transferred to the genus Baltisphaeridium (then of hystrichospheres, now of acritarchs) by Downie and Sarjeant, invalidly in 1963 (p. 90) and validly in 1964 
(p. 124), becoming B. spiculatum (White) Downie and Sarjeant. That attribution continues to appear appropriate since, though indeed there were long-spined dinoflagellate cysts in the Late Cretaceous (e.g. Raphidodinium), White's excellent figure affords no indications of dinoflagellate affinity.

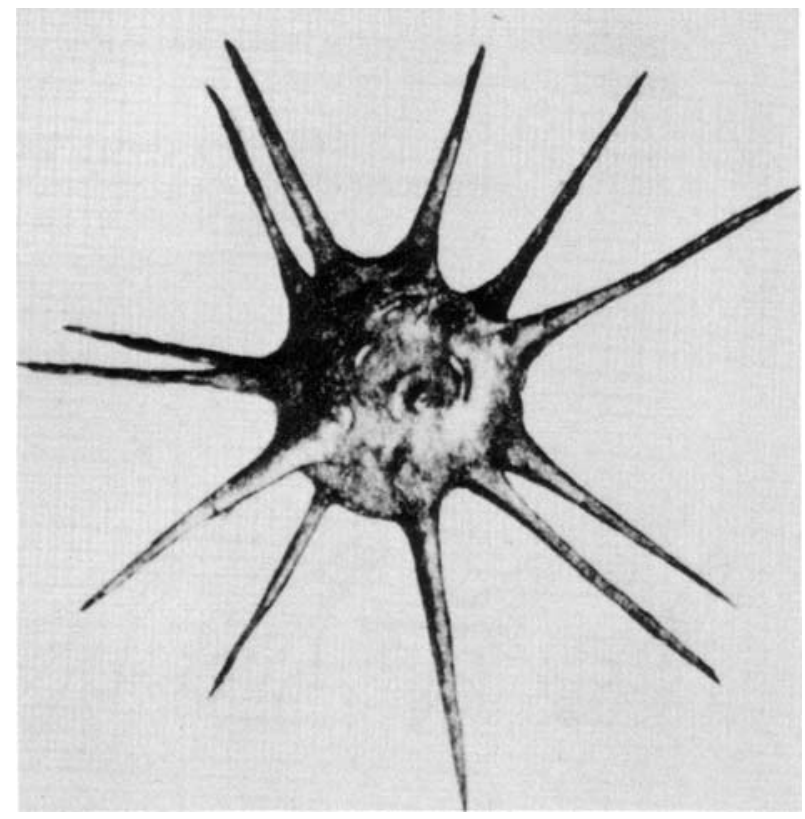

Fig 6. Xanthidium spiculatum White, 1844 b, now

Baltisphaeridium spiculatum (White) Downie and Sarjeant

\section{SUMMARY AND CONCLUSIONS}

In an age when such pioneer microscopists as C.G. Ehrenberg and Rev. J.B. Reade were content merely to give illustrative figures, of the "Xanthidia" they were studying, supplemented only by the briefest of descriptions or none at all, Henry Hopley White's work was outstanding. Though examining specimens embedded at varying depth in flint rather than "clean" specimens extracted by chemical means, he was able to make drawings that were, in general, remarkable for their precision and accuracy. Knowledge of marine palynomorphs at that time was minimal-it would be almost ninety years ere significant advances were made-and neither a standard descriptive procedure, nor even an agreed terminology, were available to him. Nevertheless he took extreme care to characterize all the morphological features that his microscope permitted him to distinguish, making careful measurements and even endeavouring to study the degree of variation between individual specimens-a refinement of observation not to be attempted again for almost a century.

Of the thirteen taxa White distinguished-the fourteenth was recognized, at the outset, as merely a variety-nine are now recognized to be certainly, and one other possibly, cysts of dinoflagellates, while another is here considered to be a Prasinophycean zoosporangium. His two other species, though quite clearly characterized, are here treated as acritarchs (and thus, of uncertain affinity).
Henry Hopley White deserves to be remembered as the most astute of the early observers of marine palynomorphs. Indeed, had he continued longer to study them, our knowledge of the marine plankton of the Cretaceous might have advanced within a few decades to a point that it was not to attain for almost another century.

\section{ACKNOWLEDGEMENTS}

I am indebted to the Honourable Society of the Middle Temple for permission to arrange photography, and to reproduce, the portrait and arms of Henry Hopley White, and in particular to Miss E. McNeill, their Librarian and Keeper of the Records, for her assistance. (The photographs were very competently taken by Mr. P.B. Howard of New Malden, Surrey). I am indebted also to Mr. Neville T. Hawson of Sheffield, Dr. W. Howard McConnell (Dept. of Law, University of Saskatchewan) and Dr. Robert A. Fensome and Dr. Graham L. Williams (Geological Survey of Canada, Dartmouth, Nova Scotia) for advice and encouragement; and to Mrs. Linda Dietz for assistance in manuscript preparation and reference-checking. This work was supported by operating grant no. 8393 of the National Sciences and Engineering Research Council of Canada.

\section{Manuscript received January 1990 \\ Manuscript accepted February 1991}

\section{REFERENCES}

Bowerbank, J.S. $1841 \mathrm{a}$. On the siliceous bodies of the Chalk, Greensands and Oolite. Proc. Geol. Soc. Lond, 3, 278-281.

Bowerbank, J.S. 184lb. On the siliceous bodies of the Chalk, Greensands and Oolite. Microsc. J. Struct. Rec, 1, 99-103; 113-115; 131-135

Bowerbank, J.S. $1841 \mathrm{c}$. On the siliceous bodies of the Chalk, Greensands and Oolite Trans. Geol Soc. Lond., 6, 181-194.

Bronn, H.G. 1848. Handbuch einer Geschichte der Narur. Dritter Band: Index palaeontologicus. E. Schweizerbart, Stuttgart, $1382 \mathrm{pp}$.

Bujak, J.P., Downie, C., Eaton, G.L. \& Williams, G.L. 1980. IV. Taxonomy of some Eocene dinoflagellate cyst species from southern England. In Bujak, J.P., Downie, C., Eaton, G.L. \& Williams, G.L., Dinoflagellate cysts and acritarchs from the Eocene of southern England. Special Papers in Palaeontology, no. 24, 26-36.

Cookson, I.C. 1953. Difference in microspore composition of two samples from a bore at Comaum, South Australia. Austral. J. Bot., 1, 462-473.

Curwen, E.C. (Editor) 1940. The journal of Gideon Mantell, surgeon and geologist University Press, Oxford, pp. 142, 152-153.

Davey, R.J. 1969. Non-calcareous microplankton from the Cenomanian of England, Northern France and North America. Pt. I. Bull. Br. Mus. (Nat. Hist.) Geol., 17 103-180.

Davey, R.J., Downie, C., Sarjeant, W.A.S. \& Williams, G.L. 1969. Appendix to "Studies on Mesozoic and Cainozoic Dinoflagellate Cysts". Bull. Br. Mus. (Nat Hist.) Geol., Suppl. 3, 24 pp.

Davey, R.J. \& Verdier, J.P. 1976. A review of certain non-tabulate Cretaceous Hystrichospherid dinocysts. Rev. Palaeobot. Palynol., 22, 307-335.

Davey, R.J.\& Williams, G.L. 1966a. The genera Hystrichosphaera and Achomosphaera. In Davey, R.J., Downie, C., Sarjeant, W.A.S. \& Williams, G.L. Studies on Mesozoic and Cainozoic dinoflagellate cysts. Bull. Br. Mus. (Nat. Hist.) Geol., Suppl. 3, 28-52.

Davey, R.J. \& Williams, G.L. 1966b. The genus $H_{y}$ strichosphaeridium and its allies. In Davey, R.J., Downie, C., Sarjeant, W.A.S. \& Williams, G.L., Studies on Mesozoic and Cainozoic dinoflagellate cysts. Bull. Br. Mus. (Nat. Hist.) Geol., Suppl. 3, 53 106.

Deane, H. 1849. On the occurrence of fossil Xanthidia and Polythalamia in $\mathrm{Chalk}$ Trans. Microsc. Soc. Lond.. 2. 77-79.

Deflandre, G. 1937. Microfossiles des silex cretaces. Pt. II. Flagelles, incertae sedis, Hystrichosphaerides, Sarcodines, Organismes divers. Annls Paleontol., 26. $51-103$.

Deflandre. G. 1946. Hystrichosphaerides II. Especes du Secondaire et du Tertiaire. Fichier micropaleom, ser. 6, Arh. Orig. Serv. Docum. C.N.R.S.. no. 235. cards $860-1019$ 
Henry Hopley White (1790-1877) and the early researches on Chalk "Xanthidia" by Clapham microscopists

Deflandre, G. \& Courteville, H. 1939. Note preliminaire sur les microfossiles des silex cretaces de Cambresis. Bull. Soc. Fr. Microsc., 8, 95-106.

Downie, C. \& Sarjeant, W.A.S. 1963. On the interpretation and status of some Hystrichosphere genera. Palaeontology, 6, 83-96.

Downie, C. \& Sarjeant, W.A.S. 1964. Bibliography and index of fossil Dinoflagellates and acritarchs. Mem. Geol. Soc. Am., 94, 180 pp.

Duxbury, S. 1980. Barremian phytoplankton from Speeton, East Yorkshire. Palaeonto graphica, ser. B, 173, 107-146.

Ellison, N.F. 1945. Samuel James Wilkinson, Author of "The British Tortrices". A biographical sketch. NWest. Nat, 19, 145-148. [Republ. in facsimile, 1982 Geol. Curator, 3, 399-401].

Harker, S.D., Sarjeant, W.A.S. \& Caldwell, W.G.E., 1990. Late Cretaceous (Campanian) organic-walled microplankton from the interior plains of Canada, Wyoming and Texas: Biostratigraphy, palaeontology and palaeoenvironmental interpretation. Palaeontographica, 219, 1-243.

Krutzsch, W. 1963. Atlas der mittel- und jungtertiaren dispersen Sporen- und Pollen-sowie der Mikroplanktonformen des nordlichen Mitteleuropas. Lieferung III: Sphagnoceoide und selaginellaceoide Sporenformen. VEB Deutscher Verlag der Wissenschaften, Berlin, $128 \mathrm{pp}$.

Lejeune, M. 1937a. L'etude microscopique des silex (2ieme Note): Un fossile anciennement connu et pourtant meconnu; Hystrichosphaera ramosa Ehrbg. Annls. Soc. Geol. Belg, 60, B239-B260.

Lejeune, M. 1937b. L'etude microscopique des silex (3ieme Note): Encore Hystrichosphaera ramosa Ehrbg.: les coques "dedoublees", le "flagelle". Annls. Soc. Geol. Belg., 60, B321-B333.

Lejeune-Carpentier, M. 1937. L'etude microscopique des silex (4ieme Note). Une interessante preparation d'Ehrenberg. Annls. Soc. Geol. Belg., 61, B59-B71.

Lejeune-Carpentier, M. 1940. L'etude microscopique des silex (8icme Note): Systematique et morphologie des "Tubiferes". Annls. Soc. Geol. Belg., 63, B216B236.

Lejeune-Carpentier, M. 1941. L'etude microscopique des silex (9ieme Note): Sur Hystrichosphaeridium hirsutum (Ehrenberg) et quelques formes voisines. Annls. Soc. Geol Belg., 64, B71-B92.

Lejeune-Carpentier, M. \& Sarjeant, W.A.S. 1981. Restudy of some larger dinoflagellate cysts and an acritarch from the Upper Cretaceous of Belgium and Germany. Annls. Soc. Geol. Belg., 104, 1-39.

Lentin, J.K. \& Williams, G.L. 1989. Fossil dinoflagellates: Index to genera and species 1989 edition. Am. Assoc. Stratigr. Palynol., Contrib. Ser., no. 20, vi + 473 pp.

Mantell, G.A. 1838. The wonders of geology. Relfe and Fletcher, Comhill, London, 2 vols., $689 \mathrm{pp}$.

Mantell, G.A. 1844. The Medals of Creation: or, First lessons in Geology and the study of organic remains. Bohn, London, 2 vols., $1016 \mathrm{pp}$.

Mantell, G.A. 1845. Notes of a microscopical examination of the Chalk and Flint of Southeast England, with remarks on the Animalculites of certain Tertiary and modern deposits. Ann. Mag. Nat. Hist., 16, 73-88.

Mantell, G.A. 1850. A pictorial atlas of fossil remains, consisting of coloured illustrations selected from Parkinson's "Organic remains of a former World" and Artis's "Antediluvian Phytology". Bohn, London, $208 \mathrm{pp}$.

Mantell, G.A. 1857. Spiniferites. In The Wonders of Geology; or, a familiar exposition of geological phenomena. Bohn, London. Seventh Edition, 2 vols, pp. 311-313.

Reade, J.B. 1839. On some new organic remains in the Flint of Chalk. Ann. Nat. Hist, 2, 191-198.

Sarjeant, W.A.S. 1959. Microplankton from the Combrash of Yorkshire. Geol Mag., 96, 329-346.

Sarjeant, W.A.S. 1962. Upper Jurassic microplankton from Dorset, England. Micropaleontology, 8, 255 268 .

Sarjeant, W.A.S. 1964. Taxonomic notes on Hystrichospheres and acritarchs. $J$. Paleontol., 38, 173-177.

Sarjeant, W.A.S. 1967. The rediscovery of a lost species of dinoflagellate c y s t : Hystrichosphaera (ex: Spiniferites) reginaldi (Mantell, 1844) comb. nov. Microscopy.J. Quekett microsc. Club., 30, 241-250.

Sarjeant, W.A.S. 1970. Xanthidia, Palinospheres and 'Hystrix'. A review of the study of fossil unicellular microplankton with organic cell walls. Microscopy. $J$. Quekett microsc. Club, 31, 221-253.

Sarjeant, W.A.S. 1973. Acritarchs and Tasmanitids from the Mianwali and Tredian Formations (Triassic) of the Salt and Surghar Ranges, West Pakistan. In Logan, A. \& Hills, L.V. (eds.). The Permo-Triassic Systems and Their Mutual Boundary. Mem. Can. Soc. Petrol Geol., no. 2, 35-73.

Sarjeant, W.A.S. 1974. Fossil and Living Dinoflagellates. Academic Press, London and New York, vii $+182 \mathrm{pp}$.

Sarjeant, W.A.S. 1978. Hundredth Year Memoriam. Christian Gottfried Ehrenberg 1795-1876. Palynology, 2, 209-211.

Sarjeant, W.A.S. 1982. Joseph B. Reade (1801-1870) and the earliest studies of fossil dinoflagellate cysts in England. J. Micropalaeontol., 1, 85-93.

Sarjeant, W.A.S. 1984. A restudy of some dinoflagellate cyst holotypes in the University of Kiel Collections. V. The Danian (Palaeocene) holotypes of Walter Wetzel (1952, 1955). Meyniana, 36, 121-171.

Stover, L.E. \& Evitt, W.R. 1978. Analyses of Pre-Pleistocene organic-walled dinoflagellates. Stanford Univ. Publ. Geol. Sci., 15, iii $+300 \mathrm{pp}$.

[Torrens, H.S.] 1982. 134. White, Henry Hopley (1790-1876). Geol. Curator, 3, 398.

Voss, E.G., Burdet, H.M., Chaloner, W.G., Demoulin, V., Hiepko, P., McNeill, J., Meikle, R.D., Nicolson, D.H., Rollins, R.C., Silva, P.C. \& Greuter, W. 1983. International Code of Botanical Nomenclature. Regnum vegetabile, vol. III. Junk, The Hague, Boston, $472 \mathrm{pp}$.

Wetherell, E.W. 1892. On the occurrence of Xanthidia (Spiniferites of Mantell) in the London Clay of the Isle of Sheppey. Geol. Mag., 9, 28-30.

White, H.H. 1842. On fossil Xanthidia. Microscop. $\boldsymbol{J}, 11,35-40$ |Republ. 1844. Trans. Microsc. Soc. Lond., 77-86].

White, H.H. 1844a. On fossil Xanthidia. Trans. Microsc. Soc. Lond. 77-86.

White, H.H. 1844b. A new species of fossil Xanthidium. Trans. Microsc. Soc Lond., 87.

Wilkinson, S.J. 1849. Observations of Xanthidium, both recent and fossil. Trans Microsc. Soc. Lond., 2, 89-92.

Yun, H.S. 1981. Dinoflagellaten aus der Oberkreide (Santon) von Westfalen. Palaeontographica, Ser. B, 177, 1-89. 